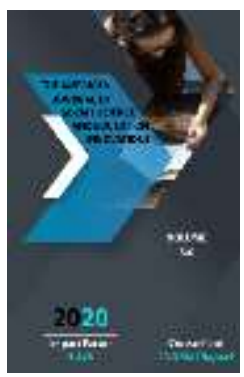

\title{
Challenges And Necessity Of Developing The National Internet Networking Segments In Uzbekistan
}

\author{
Burxanov Husniddin \\ Researcher Of The National University Of Uzbekistan, Uzbekistan
}

Journal Website: http://usajournalshub.c om/index,php/tajssei

\section{ABSTRACT}

This article examines foreign experience in the development of the national segment of the Internet in the Republic of Uzbekistan, the peculiarities and differences in the development of the national segment of the Internet in Central Asia, the problems of Internet development in Uzbekistan and the need to address them.

\section{KEYWORDS}

Globalization, information, internet, site, national segment, information flow, information need, information space, youth.

\section{INTRODUCTION}

In protecting young people from the effects of negative information, first of all, the development of sites in the national segment of the Internet plays an important role.

In this regard, a number of meetings were held in Uzbekistan dedicated to the development of the Internet and protection of young people from destructive ideas. In addition, the growing population of Uzbekistan is increasing the demand for the Internet. In particular, in 2020 the population of Uzbekistan will exceed 34 million[1] The number of Internet users has exceeded 22 million[2]. In developed countries, at least 500,000 sites serve the same population. We have 77,000 [3] sites. This, in 
turn, indicates that it is not sufficient to provide information to the population.

\section{MATERIALS AND METHODS}

Research on the problems and prospects of development of national sites was studied in 2 groups. Each of these groups sheds light on a specific aspect of the problem.

The first group is the direction of information technology, foreign researchers D.Bell[4], M.Maklyuen[5], E.Toffler[6], I.Shevchenko[7] In their work, they took a technological approach to the development of information technology and tried to create mechanisms to solve problems in this area. For example, D. Bell showed the formation of the information society in the post-industrial stage and the role of information technology in the lives of young people.

Uzbek researchers: D.Umarov[8] and G.Ibragimova[9] In their scientific work, they revealed that information security is an important issue in the use of Internet technologies.

The second group is scientific research in the field of psychology, M.Savochkin [10] and I.Kazanskaya[11] such as foreign researchers have noted that psychological methods play a key role in attracting young people to the Internet.

Uzbek researchers B.Abdulkhaev [12] and H.Khusnutdinova [13] In their research, they studied the reasons why young people are addicted to the Internet.

\section{ANALYSIS AND RESULTS}

Nowadays, the growing population of Uzbekistan is increasing the demand for the Internet. Including $2020 \mathrm{y}$. The population of Uzbekistan is over 34 million [14] and the number of Internet users has exceeded 22 million [15]. This, in turn, increases the demand for sites in the national segment of the Internet. Therefore, national sites must meet today's demand in terms of quantity and quality. In this regard, the fact that Uzbekistan lags behind the countries of the region may lead to the loss of access to information for its population. As a result, a large part of the population is exposed to foreign sites.

With this in mind, the country is paying a lot of attention to the development of Internet resources and the number of national sites is also increasing, but this is not enough. Because these results are lower than in the neighboring Republic of Kazakhstan. For example, in the Republic of Kazakhstan in 2010 there were 53,206 [16], in 2019 - 149,661 national sites (".kz" and ".qaz" domains) [17], In 2010, there were 11,088 [18] and in 2019, there were 73,734 [19] national websites (".uz" domains) in Uzbekistan.

At the same time, the number of national sites (.uz domain as of April 14, 2020) has increased to 77,318 [20], but lags behind Kazakhstan. Even taking into account the current growth rate, by December 2020, the ".kz" and ".qaz" domains could reach 160,000 , and the ".uz" domain could reach 84,000 (Figure 1). This, in turn, shows that the growth rate of sites in the national segment of the Internet in Uzbekistan, although good, lags behind countries at its level, and measures need to be taken in this regard.

In addition, when evaluating the countries of the Central Asian region in terms of the number of Internet users (Internet coverage relative to the general population) Uzbekistan lags behind its neighbor. In 2019, the rapidly growing population of Kazakhstan is estimated at 18.4 million. [21] The number of Internet users was 15.1 million [22] and the Internet coverage of the population was 82 percent. With a population of 33.5 million, Uzbekistan has 21 million Internet users. [23] and the Internet coverage of the population was 63 percent.

Currently, this figure is $65 \%$, taking into account the total population and Internet users (as of February 18,2020 , the population is more than 
34 million [24], the number of Internet users is more than 22 million [25]).

The region is home to Kyrgyzstan (population 6.4 million [26], Internet users 2.5 million, [27] Internet coverage 39 percent), Tajikistan (population 9.1 million, [28] 2.98 million Internet users, [29] Internet coverage 32.7\%) and in Turkmenistan (5.8 million, [30] 1.3 million Internet users, [31] and 22 percent Internet coverage), Internet coverage is less than 50 percent.

Today, there are many sites for the population. There are 2.2 sites per 1,000 population in the country (calculated as of February 2020 [32]). However, this figure is lower than in the neighboring Republic of Kazakhstan. Because, according to the results of 2019 (18395567 [33] population serves 149661 [34] sites) there are 8.1 sites per 1000 people. This once again shows that Uzbekistan lags behind Kazakhstan in the region in terms of the number of sites.

In today's development process, the use of mobile devices is increasing day by day. For example, the population of Uzbekistan uses about 29 million mobile devices. As a result of the development of mobile media, the number of mobile versions of Internet sites is increasing and social networks are moving to the form of messengers. In addition, the creation of mobile messengers today is increasing the interest of young people in foreign social networks.

The above points indicate that the mobile pages of the sites will develop in the future. For example, $72.4 \%$ of users access sites in the national segment of Uzbekistan through mobile applications [36].

This situation means that in the development of sites in the national segment, it is advisable to create sites that are convenient for mobile applications. In this regard, the lack of development of convenient messengers for social networks in the national segment delays the issue of attracting young people to national social networks.
Currently, $28.6 \%$ of the resources of the national segment sites of the country are educational and entertainment sites (12.6\% of educational resources, $16 \%$ of entertainment resources), indicating a strong focus on the development of educational and entertainment sites in the country [37].

It should be noted that the resources of the national segment of the Internet in the field of sports, which is given great attention in the country, is $1.1 \%$. But at the same time, it ranks high in the ranking of sports sites in the national segment of the Internet in the country, with the most users and the most in demand. For example, the site "championat.asia" ranks 9th in the ranking of sites in the national segment of the Internet in terms of daily visits of users [38]. This site is visited by 111,000 users a day[39]. This means that interest in sports-related sites is high. Because this is a big indicator for Uzbekistan.

The lack of resources in the national segment of the Internet of sports sites with high interest of young people, increases the demand for foreign sports sites. In this regard, it is necessary to increase the information on sports on the sites of the national segment. In this way, foreign sites can be left behind in the competition.

Today, young people are interested not only in sports, but also in culture, that is, in the lives of actors and artists. For example, the site "qalampir.uz", which provides "exclusive" interviews with actors and actresses on its pages, is in the top four in the ranking of sites in the national segment of the Internet. The number of daily visits to it exceeds 186,000 [40], which also means that there is a strong interest in these sites in the country. However, resources in the national segment account for 1.6 percent in this area.

At the same time, news sites are at the top of the rankings and also lead in the number of visits. For example, the site "daryo.uz" ranks first in the ranking of national sites in terms of 
the number of visits, and on March 27 this year it was visited by 1 million users[41].

Nowadays, many countries around the world are developing the field of commerce through sites. The population's interest in online stores and product advertising is growing. The fact that many young people use commercial sites will be a key factor in the development of these sites. Because young people pay attention not to the price when shopping, but to the modern form of the product. Currently, the popular sites "Alibaba.com" and "AliExpress" have made great strides in this regard, and the creation of such sites on the Internet has become a lucrative business. Currently, in the national segment of the Internet in Uzbekistan, trade-related resources account for $34.6 \%$ of total resources (business 30.1\%, e-commerce 4.5\%) [42]. In the field of trade, the site "olx.uz" is in the top five in the ranking of sites in the national segment of the Internet. The number of daily visits to him exceeds 188,000. 3 million visitors to this site in a month. user visited [44].

This also shows that there is a strong interest in sales and advertising sites in the country.

Commercial sites are also important in the development of trade in the country. In particular, national brands and offers are displayed to the whole world in a minute. This opportunity will ensure the development of the national segment of the Internet in the country and will be effective in attracting young people to the national segment in the field of trade.

In the development of trade sites, it is advisable for trade and service organizations to enrich their services and goods with information that is of interest to users (picture, price, quality of goods).

Currently, a number of decisions are being made to develop the digital economy, which also requires the development of commercial sites. This is because the implementation of services for the purchase and delivery of goods at online prices through online payments saves this time and reduces transportation costs. In addition, in the context of the spread of viruses such as "coronavirus", which has become a topical issue today, the delivery of goods through online sales to meet the needs of the population limits the movement of the population and prevents the spread of various viruses.

Nowadays, national sites in countries around the world are becoming more businessoriented and growing rapidly. Development in this area depends on promising projects in the country.

Today, young people are interested not only in trade sites, but also in social networks. But there are few users who are members of social networks in the national segment. In this regard, a number of countries in the country, such as "vsetut.uz" (601410 users) [45], "davra.uz" (21884 users) [46] and "fikr.uz" (42558 users) [47] social networking activities are not effective.

One of the main reasons for this is that they do not have interesting and effective ways to engage young people. In this regard, the number of users of "Telegram Messenger" (2 million people), "Odnoklassniki" social network (1.7 million people) and "Facebook" social network (850 thousand people) [48] is growing day by day and they have unique ways of engaging young people.

In particular, the size of their audience and the high speed of performance attract young people.

Experts also note that the main advantages of the social network Facebook, which has achieved great success today, are:

- The use of bright colors in the design;

- Structural convenience, ability to form groups, start blogs and discuss;

- Ability to receive news and information quickly;

- Possibility to upload photos and videos;

- availability of online games; 
- high chances of conversation, informing friends about their every move;

- Opportunity to make friends with celebrities;

- Opportunities for advertising;

- Ability to conduct surveys.

The above analysis also shows that the number of members and visits to social networks in the national segment is low. In addition, the "Telegram messenger", "Odnoklassniki" and "Facebook" social networks have more conveniences than national social networks. Such cases indicate that the performance of national sites is unsatisfactory. At the same time, increasing the number of visits is an important issue in the development of social networks. To do this, it is necessary to focus on improving the technical aspects, such as "Facebook" and "Odnoklassniki", interesting topics, interesting articles and design issues.

Otherwise, the country's youth will be connected to Facebook and Odnoklassniki. As a result, young people can be exposed to destructive ideas through the Internet.

In general, today the national segment of the Internet in the country faces the following problems in the development of sites and protection of young people from the influence of destructive ideas:

- The country lags behind the state of Kazakhstan in its region in terms of the number and quality of national sites;

- The country is losing access to information through the sites of the national segment of the Internet, and as a result, a large part of the population receives information from foreign sites;

- At a time when young people mainly use messengers, the issue of creating national messengers remains open;

- Young people are mainly transferred to foreign social networks;

- There are cases of young people indulging in various destructive ideas through social networks;
- At a time when young people are very interested in sports sites, our national sites do not have enough information about it;

- National trade sites are not in demand today's position and they have not enough comforts.

\section{CONCLUSION}

In general, the main problem is that the infrastructure in the country is not in demand, and at the same time there are insufficient funds for the implementation of major projects in the development of the industry and a number of shortcomings in the development of national Internet segment sites.

The main shortcomings of the national segment of the Internet in this regard are the lack of interactive services, lack of content and attractiveness, lack of involvement in the design of sites and ineffective mechanisms for attracting young people.

\section{REFERENCES}

1. https://kun.uz/news/2020/02/18/ozbekisto n-aholisi-34-million-kishidan-oshdi, 18.02.2020.

2. http://mitc.uz/uz/news/view/117ohttp://mi tc.uz/uz/news/view/1170,04.02.2020.

3. https://cctld.uz/stat/14.04.2020.

4. Bell D.The Coming of Post-industrial Society.A Venture in Social Forecasting. N.Y., BasicBooks, Inc., 1973.

5. McLyuen M., Gutenberg's Galaxy: The Becoming of a Printing Man. -Moscow; 2005.

6. Toffler E. The third wave. M.: AST, 2004.

7. Shevchenko I.A. Political Internet technologies in transforming societies: Author's abstract. diss ... cand. polit. sciences. - Stavropol: 2005.

8. Umarov I.T. Current issues of information security in the context of globalization: Diss ... master. works. - Tashkent: STIBOM, 2013 ;

9. Ibragimova G.I. Global information space in the formation of a new world order: 
Abstract. diss ... cand. polit. sciences. Tashkent: UWED, 2012.

10. Savochkin M.P. Psychological threats of the Internet. // Proceedings of the scientific-practical conference on security psychology (2008 March 15) .- T.: STIBOM, 2008.B.251.

11. Kazanskaya I.A. Social functions of Internet technologies: Author's abstract. diss ... cand. philosopher of sciences. Moscow: 2011.

12. Abdulkhaev B.A. Information psychological expansion as a threat to national security.// Proceedings of the scientific-practical conference on security psychology.-T., 2008;

13. Khusnutdinova Kh.Kh. Creation of an information system for assessing the manageability of organizational structures.diss ... doc. Econ. sciences. T :. 2007.

14. https://kun.uz/news/2020/02/18/ozbekisto n-aholisi-34-million-kishidan-oshdi, 18.02.2020.

15. http://mitc.uz/uz/news/view/117ohttp://mi tc.uz/uz/news/view/1170,04.02.2020

16. https://kursiv.kz/news/hi-tech/2011-02/za2010-god-pochti-20-tys-zayavok-bylopodano-na-registraciyu-domenov$\mathrm{v}, 02.04 .2020$.

17. https://profit.kz/news/57067/Itogi-2019Kaznet/ 12.04.2020.

18. https://cctld.uz/stat/12.04.2020.

19. Статистика. URL:http://https://cctld.uz/ 02.01.2020.

20. https://cctld.uz/stat/14.04.2020.

21. https://ru.wikipedia.org/wiki/Население_ Казахстана/10.04.2020.

22. https://kursiv.kz/news/obschestvo/201910/kakoe-mesto-zanyal-kazakhstan-poskorosti-interneta/10.04.2020.

23. The number of Internet users will reach 20 million in 2018 and 22 million in 2020. split 2019 has not been officially announced, but about $21 \quad$ million. http://mitc.uz/uz/stat/4//10.04.2020.
24. https://kun.uz/news/2020/02/18/ozbekisto n-aholisi-34-million-kishidan-oshdi, 18.02.2020.

25. http://mitc.uz/uz/news/view/117ohttp://mi tc.uz/uz/news/view/1170,04.02.2020 .

26. https://ru.wikipedia.org/wiki/Население_ Киргизии/10.04.2020.

27. http://kabar.kg/news/kolichestvointernet-pol-zovatelei-kyrgyzstanaezhegodno-rastet-dogoev/10.04.2020.

28. https://ru.wikipedia.org/wiki/Таджикиста $\mathrm{H} / 10.04 .2020$.

29. https://tajikta.tj/ru/news/v-tadzhikistanechislo-polzovateley-interneta-sostavilookolo-3-mln-abonentov/10.04.2020.

30. https://ru.wikipedia.org/wiki/Туркмения/1 0.04.2020.

31. https://mlsp.gov.tm/ru/newspapers/771/10 .04 .2020 .

32. Статистика. URL:https://cctld.uz/ 01.03.2020.

33. https://ru.wikipedia.org/wiki/Население_ Казахстана/10.04.2020.

34. https://profit.kz/news/57067/Itogi-2019Kaznet/12.04.2020.

35. Kun.uz сайти. "About 29 million mobile devices have been registered in Uzbekistan. Are they being tracked now?" 04.11.2019.

36. Статистика. URL:http://www.uz02.04.2020.

37. Статистика. URL: http://www.uz 102.04.2020.

38. https://www.uz /02.04.2020.

39. https://www.uz/ru/res/visitor/index?id=20 501\&page $=1 / 16.03 .2020$.

40. https://www.uz/ru/res/visitor/index?id=34 814/26.03.2020.

41. https://www.uz /02.04.2020.

42. https://www.uz/ 02.04.2020.

43. https://www.uz/ru/res/visitor/index?id=12 03/20.03.2020.

44. http://uz.infocom.uz/2020/04/o9/hozirgipaytda-ozbekistonliklar-olxda-koproqnimalarni-qidirayotganianiqlandi/09.04.2020

45. https://vsetut.uz/blogs/user/1781708/15.04 .2020 . 
The American Journal of Social Science and Education Innovations (ISSN - 2689-100x)

Published: August 29, 2020 | Pages: 557-563

Doi: https://doi.org/10.37547/tajssei/Volume02Issue08-92

46. http://davra.uz/15.04.2020.

47. http://fikr.uz/people/ 15.04.2020.

48. https://theopenasia.net/ru/post/kakiesotsseti-populyarny-v-tsentralnoy-azii 15.04.2020. 